\title{
Bronchų astma: teorija ir praktika
}

\author{
Doc. dr. Diana Barkauskienè \\ KMU Pulmonologijos ir imunologijos klinika
}

\begin{abstract}
Gydant astmą siekiama ne tik apsaugoti pacientą nuo astmos paūmėjimų, bet ir sudaryti sąlygas gyventi visavertį gyvenimą kontroliuojant ligą. Vaistus astmai gydyti galima skirti į dvi grupes: simptominius ir kontroliuojamuosius.

Pirmieji yra beta 2 agonistai, šalinantys ar lengvinantys ligos simptomus, 0 antrieji - gliukokortikosteroidai, vartojami nuolatos, kad nepasireikštų astmos simptomų. Inhaliuojamieji gliukokortikosteroidai dažnai derinami su ilgai veikiančiu beta 2 agonistu (IVBA).
\end{abstract}

\section{ASTMOS GYDYMAS}

GINA rekomenduoja pakopini astmos gydymą. Ivertinus, kaip astma kontroliuojama ir koks tuo metu gydymas taikomas, pacientas priskiriamas vienai iš penkių gydymo pakopų. Vèliau gydymas parenkamas ir keičiamas atsižvelgiant i paciento ligos kontrolès lygmenị. Jei tris mènesius gydoma astma išlieka tik iš dalies kontroliuojama, būtina intensyvinti paciento gydymą, jei astma lieka visai nekontroliuojama, rekomenduojama pereiti prie aukštesnés pakopos gydymo. Jei astma kontroliuojama ne trumpiau kaip tris ménesius, pereinama prie viena pakopa žemesnio gydymo ir siekiama parinkti žemiausią, tačiau astmos kontrolę garantuojančią gydymo pakopą bei mažiausią vaistų dozę.

Anksčiau negydyti pacientai pradedami gydyti antros pakopos vaistais. Tai tinka lengva astma sergantiems pacientams, tačiau, jei astma vidutinio sunkumo ar sunki, iš karto skirtini trečios pakopos vaistai.

\section{Gydymas inhaliuojamaisiais gliukokortikosteroidais}

Visos tarptautinès rekomendacijos teigia, kad svarbiausias ilgalaikio astmos gydymo tikslas - kvėpavimo taku uždegimo slopinimas, o būtent nepakankamas kvejpavimo takų uždegimo gydymas yra blogos simptomų kontrolès priežastis. IGKS astmos ligoniui yra būtini, turi būti vartojami ilgą laiką ir reguliariai. Net mažos IGKS dozès daugeliui pacientu greitai pagerina klinikinius simptomus ir plaučiu funkcijos rodiklius [24].

Astma - lètinè kvèpavimo taku uždegimo liga. Ja sergant nustatoma bronchų liauku hipertrofija, padidè- jęs taurinių ląstelių skaičius, židininè fibrozè, sustorèjęs savasis gleivinès dangalas, lygiụjų raumenų hipertrofija, bronchų sekreto kamštukai kvèpavimo takų spindžiuose. Kvejpavimo takų persitvarkymas ilgalaikio uždegimo padarinys, o nepakankamas uždegimo slopinimas vaistais skatina formuotis negrižtamus pokyčius. Dar daugiau - bronchų biopsinès medžiagos tyrimai rodo, kad kvępavimo takų struktūriniu pokyčių atsiranda jau ankstyvoje ligos stadijoje [24], o asmenų, sergančių lengva intermituojančia astma, bet nevartojančiuc IGKS, pokyčiai didesni nei ligonių, vartojusių IGKS [4].

Anksti paskyrus uždegimą slopinantị gydymą galima sumažinti bronchų reaktyvumą, stabdyti kvejpavimo taku persitvarkymo procesą ir pagerinti klinikines baigtis. Irodyta, kad delsimas skirti IGKS lemia struktūrinių pokyčiu didejimą net sergant nesunkia astma. Atliktas tyrimas, kurio metu matuotas kvejpavimo takų biopsinès medžiagos tinklinès pamatinès membranos storis $(\mathrm{Rbm}, \mu \mathrm{m})$ sveikiems ir sergantiems astma asmenims. Gauti rezultatai rodo, kad tinklinès pamatinès membranos storis buvo daug didesnis pacientu, sergančių lengva astma, nei sveikujjų, ji storesnè ir lengva astma sergančių asmenų, kurie nevartoja IGKS, nei tuc, kurie gydomi IGKS [4]. Nustatyta, kad didesnès IGKS dozès veiksmingiau stabdo persitvarkymą nei mažos (1 pav.) [5].

START (angl. The Inhaled Steroid Treatment As Regular Therapy in Early Asth$m a)$ klinikinio tyrimo duomenimis, lengvos astmos atveju anksti skirtas IGKS (budesonidas) labai pagerino astmos kontrolę ir sumažino papildomų vaistų vartojimą [6]

Taigi IGKS yra veiksmingiausi kvėpavimo takų uždegimą slopinantys vaistai ir vilkinimas juos skirti lemia struktūrinių pokyčiuc didejjimą ir ligos eigos blogejjimą.
Vienas iš GINA iškeltų ilgalaikès astmos kontrolès tikslu - minimalus astmos paūmèjimų skaičius. Astmos paūmejjimų daug geriau išvengti, nei juos gydyti. Daugelis pacientu prieš astmos paūmejjimą jaučia perspéjamuosius simptomus, ir tik po kelių dienų pasireiškia patys sunkiausi. Taigi yra laiko, kai galima užkirsti kelią paūmèjimui [7, 10]. Dažnai, atsiradus simptomų, pacientai patys reguliuoja savo gydymą. Trumpo poveikio beta 2 agonistai, kurie neslopina uždegimo, didesnèmis dozèmis vartojami tik atsiradus pirmiesiems paūmejimo simptomams. Tuo tarpu IGKS gerai slopina uždegimą ir paūmèjimo simptomus, tačiau dažnai jų dozè padidinama pavèluotai, dèl to paūmèjimas stiprèja [7]. Siekiant išvengti sunkių astmos paūmèjimų, reikalingas lankstus, pagal klinikinę situaciją pritaikomas gydymo būdas. Irodyta, kad padvigubinus IGKS dozę, kai pajuntami perspejamieji astmos paūmejjimo simptomai, sunkaus astmos paūmejjimo galima išvengti ar bent palengvinti eigą, sumažinti geriamųjų gliukokortikosteroiduc vartojimą $[8,9]$.

Reguliarus IGKS vartojimas daugiau kaip 30 proc. sumažina ligos paūmejjimo ir hospitalizavimo atveju, palyginti su nereguliariu [11, 12]. Vadinasi, kuo ilgiau (reguliariai) ligonis vartos IGKS, tuo juc palankus poveikis bus reikšmingesnis.

\section{Gydymas beta 2 agonistais}

Bronchus plečiantys vaistai atpalaiduoja bronchų lygiuosius raumenis ir sumažina bronchų spazmą. Inhaliuojamieji beta 2 agonistai yra veiksmingiausi bronchus plečiantys vaistai, skiriami astmai gydyti. IVBA kartu su IGKS rekomenduojama skirti visiems (jei nèra kontraindikaci- 


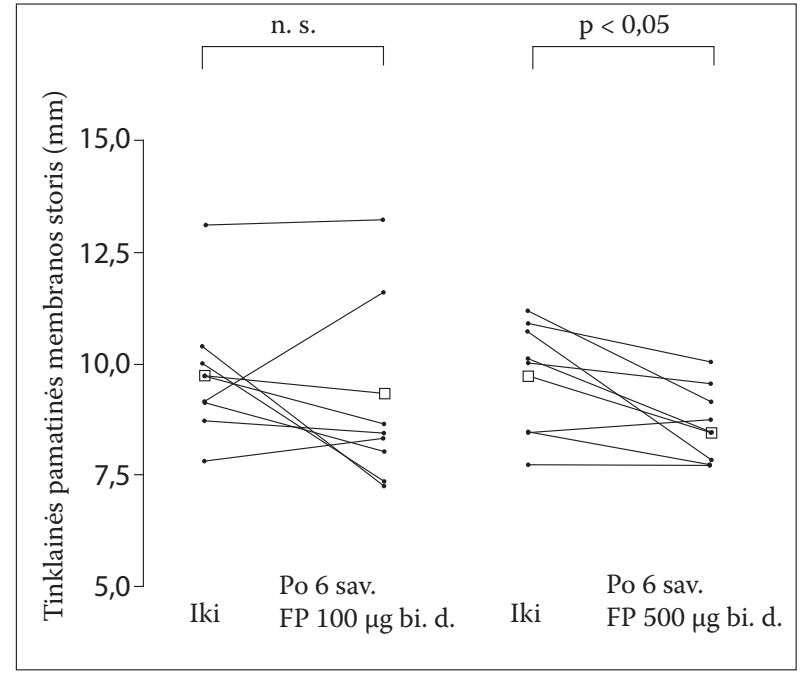

1 pav. DIDESNĖS IGKS DOZĖS VEIKSMINGIAU MAŽINA STRUKTÜRINIUS POKYČIUS

ChetaA.irkt.,Am.J.Respir.Crit.CareMed.2003http://arccm.atsjournals.org/content/vol167/issue5/ images/large/200207-7100Cf5.jpeg

jų) pacientams, kuriems taikomas ketvirtos ir penktos pakopos gydymas. Trečiojoje pakopoje IVBA kartu su IGKS gali būti skiriami kaip vienas iš gydymo būdų. Tačiau vartojami reguliariai jie praranda savo veiksmingumą (tachifilaksija), silpnejja bronchus plečiantis poveikis ir apsauginès savybės, gebėjimas sumažinti bronchu reaktyvumą.

Išanalizavus daugelio tyrimų duomenis įrodyta, kad prie reguliariai bent vieną savaitę vartojamų beta 2 agonistų organizmas pripranta, ir ligos kontrole būna blogesnè nei vartojant placebą [13].

IVBA gerokai padidina ligos paūmejjimų ir mirties nuo astmos riziką [14]. IVBA nuolatiniam astmos gydymui be IGKS skirti negalima, nes kuo ilgiau ir reguliariau ligonis vartos IVBA, tuo jų veiksmingumas bus silpnesnis, o nepageidaujamas poveikis stipresnis. IVBA lengvina astmos simptomus: kosulį, švokštimą, dusulį, bet uždegimo procesas tęsiasi ir turi būti gydomas IGKS.

Nesunkia astma sergantiems pacientams pirmiausia turi būti skiriama pakankama IGKS dozé. Jei gydant tinkamomis IGKS dozèmis išlieka reikšmingu astmos simptomų arba astma yra vidutinio sunkumo ar sunki, gydymą rekomenduojama papildyti IVBA. OPTIMA [16] klinikiniame tyrime pacientai, sergantys lengva persistuojančia astma, buvo suskirstyti i dvi grupes (A grupé asmenys, niekada negydyti IGKS, B grupe - IGKS gydyti pacientai). A grupès pacientai gydyti budezonido $100 \mu \mathrm{g} 2 \mathrm{k}$. per parą, budezonido $100 \mu \mathrm{g} 2 \mathrm{k}$. per parą ir formoterolio 4,5 $\mu \mathrm{g}$ arba placebu. B grupès pacientai budezonido $100 \mu \mathrm{g} 2 \mathrm{k}$. per parą, budezonido $100 \mu \mathrm{g}$ $2 \mathrm{k}$. per parą. ir formoterolio $4,5 \mu \mathrm{g}$ arba budezonido $200 \mu \mathrm{g} 2 \mathrm{k}$. per parą ir formoterolio 4,5 $\mu \mathrm{g}$. A grupès pacientu gydymo rezultatai rodo, kad geriausiai astma buvo kontroliuojama taikant monoterapiją budezonidu: per vienerius metus nekontroliuojamos astmos dienu buvo 7,3 proc., o papildomai skiriamas formoterolis tokiems ligoniams simptomu kontrolès nepagerino (nekontroliuojamos astmos dienu per metus buvo 8,3 proc.). Nustatyta, kad ligoniams, sergantiems lengva persistuojančia astma, kurie dar nebuvo gydyti IGKS, budezonidas 60 proc. sumažino astmos paūmejjimo ri- ziką ir 48 proc. nekontroliuojamos astmos dienų skaičių, palyginti su placebu. B grupès rezultatai rodo, kad IGKS jau anksčiau gydytiems pacientams papildomai skirtas formoterolis sumažino paūmejjimo riziką ir nekontroliuojamos astmos dienų skaičių nuo 43 iki 30 proc., o gydymas formoteroliu buvo efektyvesnis nei padvigubinta budezonido doze.

IVBA gali slèpti uždegimą. İrodyta, kad, nors simptomų nèra, plaučių funkcijos rodikliai geri, savaitę prieš astmos paūméjimą skrepliuose daug didesnis skaičius eozinofilu buvo rastas pacientams, vartojusiems salmeteroli, palyginti su placebu (atitinkamai 19,9 ir 9,3 proc.) [15]

\section{Gydymas sudėtiniais IGKS ir IVBA preparatais}

Šiuo metu plačiai vartojami sudètiniai IGKS ir IVBA preparatai. IGKS kartu su IVBA veikia sinergiškai, todèl galima sumažinti IGKS dozes. Tačiau reikia turèti omenyje, kad didesnès IGKS dozès kvėpavimo taku uždegimą slopina veiksmingiau [5]. Ir tik tuo atveju, jei didelèmis IGKS dozèmis nepavyksta gerai kontroliuoti astmos, papildomai reguliariam gydymui galima paskirti IVBA.

Kai IGKS ir IVBA skiriami kartu, jų galima ịkejpti iš atskiru ar iš vieno inhaliatoriaus (fiksuotas IGKS ir IVBA derinys). Kiekvienas šių būdų turi privalumų ir trūkumų [17]. Svarbiausias privalumas tas, kad patogiau vartoti (tik vienas inhaliatorius). Tačiau ne visada imanoma paskirti tinkamą IGKS dozę, kai astma yra nevisiškai kontroliuojama. Be to, fiksuotų dozių inhaliatoriai skiriami tais atvejais, kai pakaktų vienų IGKS, neatitinka pakopinio gydymo rekomendacijuc.

GOAL (angl. Gaining Optimal asthma Control) tyrimas rodo, kad skiriant sudetinių preparatų, taikant reguliarų nuolatinį astmos sunkumą atitinkantị gydymą, pritaikant dozę individualiai, galima smarkiai pagerinti astmos kontrolę [18]. Tyrimas apemè tris pacientų, kurių astma nebuvo kontroliuojama iki tyrimo pradžios, grupes: iki tyrimo nevartojusių IGKS, vartojusių mažas ir vidutines IGKS dozes. Vienerius metus trukusiame tyrime dalyvavo 3421 pacientas. Vienos grupès pacientams buvo skiriamas pakopinis gydymas flutikazono propionatu, kitos - flutikazono propionato ir salmeterolio deriniu. Daugiau pacientu gera astmos kontrolè buvo pasiekta vaistu deriniu, o ne vienu flutikazonu. Tačiau, esant vidutinio sunkumo astmai, šis skirtumas nedidelis (tik 8 proc.), todèl tai dar kartą įrodo, kad gerą astmos kontrolę sergantiems vidutinio sunkumo astma galima pasiekti ir taikant tik monoterapiją IGKS. Flutikazono ir salmeterolio deriniu gydytiems pacientams, pasiekus visišką kontrolę, simptomu neatsirado 81 proc. savaičių, o tiems, kuriems pasiekta gera kontrolè, simptomų nebuvo 86 proc. savaičių.

GOAL tyrimo rezultatai rodo, kad, neatsižvelgiant i ligos sunkumą, daugumai astma sergančių pacientų įmanoma pasiekti ligos kontrolę ir pasiektąją išlaikyti.

Taigi nereguliariai ir nepakankamai gydantis IGKS, didejja tikimybé ligos paūmèjimų bei kvẻpavimo takų persitvarkymo, lemiančio nepataisomus padarinius: stabilią bronchų obstrukciją, menkai pasiduodančią beta 2 agonistų poveikiui. Sumažejejus ar net išnykus simptomams, astmos gydymas ligą kontroliuojančiais vaistais (IGKS ar jų deriniais su IVBA) dar turètų būti tęsiamas gan ilgai. Vèliau dozę galima mažinti ir gydy- 


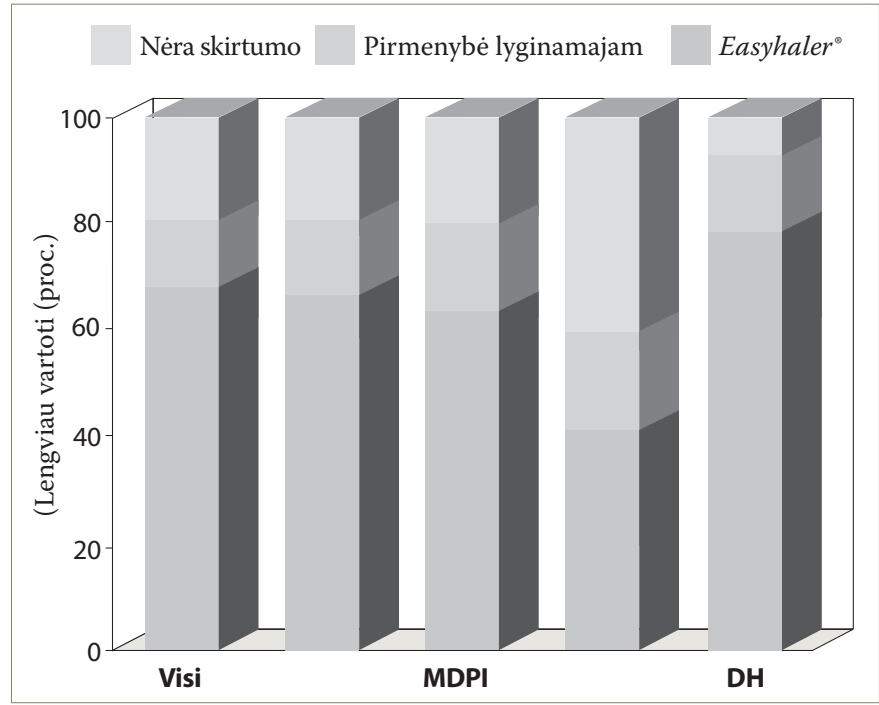

2 pav. INHALIATORIŲ PASIRINKIMO GALIMYBĖ

mą tęsti mažesne doze, išlaikant astmos kontrolę, kaip rekomenduoja pakopinio astmos gydymo principai.

Deja, klinikinèje praktikoje astmos kontrolè nuo GINA siekiamų tikslų labai skiriasi [19]. Daugelis pacientų jaučia simptomus dieną ar naktị bent kartą per savaitę, turi skubiai atvykti pas gydytojus, astma riboja jų kasdienę veiklą.

\section{INHALIATORIŲ NAUDOJIMAS IR JŲ SAVYBE்S}

Viena pagrindinių sąlygų, norint pasiekti gerą astmos kontrolę, - taisyklingas inhaliatoriaus naudojimas. Šiuo metu klinikinejje praktikoje naudojama ịvairių konstrukcijų ir veikimo mechanizmo vaistu inhaliatorių. Gydytojui gali būti nelengva parinkti geriausią, tinkamiausią konkrečiam pacientui, atsižvelgus i jo amžių, ligos pobūdị ir sunkumą, reikalingų dozių skaičiuc, vaisto toleravimą ir kitas aplinkybes.

Svarbu, kad gydytojas, paskyręs pacientui nustatytą veikliosios medžiagos dozę, būtų tikras, kad tokią dozę pacientas ir gavo. Be to, svarbu, kad išleista ir iš inhaliatoriaus atsipalaidavusi smulkių dalelių dozé, kiekvieną kartą naudojant inhaliatorių sutaptų. Kaip parodė atlikti tyrimai, kai kurių konstrukcijų inhaliatorių išleistoji ir atsipalaidavusi dozès gali skirtis net 18 procentų [19]. Kaip minèta, labai reikšmingas praktinis inhaliatoriaus pranašumas - nesudètingas, lengvas jo naudojimas. Todèl pacientui parinkti tinkamą inhaliatorių yra taip pat svarbu kaip ir vaistą astmai gydyti.

Dozuoti aerozoliniai inhaliatoriai (DAI) pasaulyje vis dar išrašomi dažniausiai. Tačiau daugeliui ligonių kyla sunkumų juos naudojant. Ligonis turi suderinti ikvėpimą su vaistų atsipalaidavimu. Tyrimas rodo, kad 71 proc. pacientų turejjo problemų, naudodami šị inhaliatorių, ir beveik pusès jų astma buvo kontroliuojama tik iš dalies [19]. Netgi taisyklingai naudojant DAI, tik 20 proc. atsipalaidavusios vaisto dozès pasiekia plaučius, o didelè dalis vaisto lieka burnoje ar rykleje [19]. Be to, kai kuriems ligoniams šaltos aerozolio dalelès sukelia nosiaryklès dirginimą, kosuli, ir ligonis savaime nutraukia pradètą ịkvèpimą. Tarpinès, naudojamos kartu su DAI, iš dalies gali išspręsti šias problemas. Didesnè dalis vaisto dozés pasiekia plaučius ir pagerina klinikini efektą, mažiau vaisto nusèda burnoje ar rykleje.

Šiuo metu klinikinejje praktikoje vienas iš inhaliuojamųjų prietaisų yra Easyhaler („Berlin-Chemie Menarini“). Svarbiausia jo savybè smulkių dalelių vienodumas. Be to, vaistų atsipalaidavimas nepriklauso nuo kvėpavimo - tai išsprendè ikvèpimo reguliavimo problemą, nereikia derinti ịkvépimo ir inhaliatoriaus paspaudimo, kaip vartojant DAI. Buvo nustatyta, kad, naudojant DMI, vaistu i plaučius patenka du kartus daugiau [19]. Labai naudinga ir tai, kad dozè nepriklauso nuo paciento įkvėpimo greičio ir stiprumo, t. y. net vidutiniškai ịkvèpus, Easyhaler esantys vaistai gerai patenka ị plaučius, o tai labai svarbu sunkiai sergantiems ligoniams ir vaikams, kurie nesugeba pasiekti reikiamo ịkvejpimo tẻkmès greičio [20].

Lietuvoje vartojami Easyhaler yra pripildyti šių veikliųjų medžiagų:

- gliukokortikosteroido budezonido („Neplit“);

- greito/ilgo veikimo beta-2 agonisto formoterolio („Diffumax“);

Atskiru inhaliatoriu Easyhaler naudojimas sudaro sąlygas keisti gydymo intensyvumą, parinkti ịvairius preparatu ir dozių derinius ir taip pasiekti reikiamą atsaką pagal ligos sunkumą, be reikalo nevartoti antro vaisto. Taip galima gydyti astmą pagal GINA $2006 \mathrm{~m}$ rekomendacijas: kai ligai kontroliuoti reikia tik monoterapijos IGKS, galima ligoniui skirti budezonido. Prireikus, gydymą galima papildyti formoteroliu, o pasiekus simptomų kontrolę, vèl grịžti prie monoterapijos IGKS.

Parenkant inhaliatoriu labai svarbu, ar prietaisas yra priimtinas pacientui, reikia issitikinti, ar lengva ji bus naudoti. Devynių klinikinių tyrimų (802 pacientai) metaanalizè parodè, kad $60-75$ proc. sergančiujuc astma, pasirinkdami inhaliatorių, pirmenybę teiktų Easyhaler (2 pav.) [22].

Taigi Easyhaler būdingos svarbiausios inhaliatoriaus savybės: smulkių dalelių dozès vienodumas, nuo ikvėpimo greičio nepriklausomas veikimas, pacientu teikiama pirmenybè.

\section{LITERATŪRA}

1. S. Holgate, H. Bisgaard et al. The Brussels declaration: the need for change in asthma management. Eur Respir J 2008; 32: 1433-1442.

2. World Health Organization. Bronchial Asthma Fact Sheet 2000

3. Lugogo N.L. et al. Epidemiology of asthma. Clinics in chest medicine 2006 27: 1-15.

4. Shiba K., Kasahara K., Nakajima H., Adachi M. Structural changes of the airway wall impair respiratory function, even in mild asthma. Chest 2002; 122: 1622-1626.

5. Cheta A., Zanini A., Foresi A., Donno M. et al. Vascular component of airway remodeling in asthma is reduced by high dose of fluticasone. Am J Respir Crit Care Med 2003; 167:751-757.

6. W. Busse, S. Pedersen, R. Pauwels et Al. The Inhaled Steroid Treatment As Regular Therapy in Early Asthma (START) study 5-year follow-up: Effectiveness of early intervention with budesonide in mild persistent asthma. J Allergy Clin Immunol 2008; 121: 1167-1174.

7. Partridge M.R. et al. attitudes and actions of asthma patients on regula maintenance therapy: the INSPIRE study. BMC Pulmonary Medicine 2006

8. Harrison, TW; Oborne, J; Newton, S, et al. Doubling the dose of inhaled corticosteroid to prevent asthma exacerbations: randomised controlled trial. Lancet. 2004;363:271-5.

9. Harrison TW et al. Doubling the dose of inhaled corticosteroid to prevent asthma exacerbations: randomized controlled trials. Lancet 2004, 363: 271-275.

10. Asthma exacerbations: prevention is better than cure. The Gaining Optimal Asthma ControL study. Am J Respir Crit Care Med. 2004;170:836-44.

11. Suissa $S$, Ernst $P$ et al. Low-dose inhaled corticosteroids and the preven tion of death from asthma. N Engl J Med 2000; 343:332-336

Kiti literatūros šaltiniai redakcijoje (iš viso 27). 